\title{
The Role of ABC Books and Dictionaries at the End of XIX - the Beginning of the XX Century in the History of the Bashkir Literary Language
}

\author{
Rida Latypova, Gulkay Samirkhanova*, Nailya Lasynova, Zulfiya Akhmetzadina and Liliya Absalyamova \\ Sibay institute (branch) of "Bashkir State University", Russia
}

\begin{abstract}
The present work is devoted to the linguistic analysis of the first Bashkir ABC books, textbooks and dictionaries compiled on the basis of the Russian script at the end of XIX - the beginning of the XX centuries. The linguistic characteristics, the graphic and phonetic analysis, comparison of the written sources with dialects of the modern Bashkir literary language are the main directions in which the research was conducted. In this work, proceeding from the character and the purpose of the studied material, the widely applied in linguistics descriptive (i.e. the careful description of each separate source at the level of a graphophonetics, graphomorphology, morphology) and historical and comparative (comparison of separate historical stages of development of the Bashkir literary language) methods are used. The results of the research allow to find out the influence of the studied sources on formation and development of the Bashkir writing and language standards of the literary language. During this period a new type of the Bashkir literary language, different from Turkic began to be formed, i.e. Bashkir gained recognition as an independent language with the writing based on the Russian script.
\end{abstract}

\section{Introduction}

Any modern literary language is the result of historical development implementing diverse and complicated relations of the present with the past and future. The literary language due to its nature is directly connected with a writing system as it can form and develop only within it.

The Bashkir writing during its existence used three types of scripts: in the VII-XII centuries - runic script, from the XIII century to the 20 -s of the XX century Arabic script, from 1930 to 1940 - Latin and since 1941 - Cyrillic alphabet. The Russian alphabet instead of the Arabic-Bashkir one was offered at the end of XIX - the beginning of the XX centuries by the Russian scientists and the Bashkir national intelligentsia.

Bashkir ABC books, textbooks, dictionaries and folklore collections, data on Bashkir grammar and the translations of religious books on the basis of Cyrillics and the Latin script were published by the Russian, Bashkir, foreign scientists and teachers at that period. Undoubtedly, the purposes of studying Bashkir were different. The scientists wanted to to investigate the language on the scale of not only Russia, but also the whole Europe, while the Russian missionaries put the task to involve the Bashkir people in Christianization process. The representatives of the national intelligentsia sought to raise the status of the native language to the literary level, thus making it clear and close to the people, to increase the culture of the Bashkir people, to bring it closer to the Russian and world culture. They made the first attempts to create Bashkir national writing on the basis of the Russian script. Despite the purposes of these editions at that time, now they have turned into one of the sources for the study of the Bashkir language history.

The main distinctive sign of the Bashkir written sources at the end of the XIX - the beginning of the XX century is that their language was folk and very close to live Bashkir informal conversation. These sources are the first experiences of creating new type of the Bashkir literary language and its writing, finding opportunities for its further development. Therefore studying of their language gives valuable actual material on history of the Bashkir literary language, plays an important role in reconstruction of its general state. Their scientific assessment is the major task of Turkic linguistics as well as Bashkir.

\section{Materials and methods}

Written sources play a huge role in linguistic research as it is impossible to study language history, to connect its modern state with early stages of development without linguistic analysis of the written sources. In order to present language history, it is important not only to investigate separate written sources, but also to define

*Corresponding author: gulysib@mail.ru 
their features which have remained in the modern language.

The achievements of modern philological science, the works of native linguists, scientists-turcologists devoted to history of the literary language, in particular, works of Russian (O.I. Blinova, V.V. Vinogradov, S.I. Kotkov, L.I. Shelepova, etc.) linguists, Bashkir (K.Z. Akhmerov, I.G. Galyautdinov, T.M. Garipov, M.V. Zaynullin, E.F. Ishberdin, N.H. Ishbulatov, J.G. Kiyekbayev, V.Sh. Psyanchin, G.G. Saitbattalov, Z.G. Uraksin, R.H. Khalikova, etc.) and others Turkic (B.A. Abilkhasimov, M.I. Borgoyakov, S.P. Gorsky, A.G. Karimullin, I.V. Mukina, P.A. Sleptsov, H.H. Khamidov, V.H. Khakov, A.Sh. Yusupova etc.) scientists have formed the methodological and theoretical basis of the research.

At the beginning of the last century, P.I. Melioransky noted that written sources are the main material in a language history research. According to B.A. Serebrennikov, "the history of each literary language is history of a written language, that is history of use of various types of written sources". In these sourcess the condition of language of this or that period, its feature, a development tendency are reflected. One cannot but agree with L.I. Shelepova's opinion that "expedient, productive development of linguistics depends not only on methods of research and their improvement, but also on the character, structure and study of the sources which are a material (actual) base of a research" [1, page 5]. Understanding a source language material, its complete description, definition of its place and role in development of the Bashkir literary language are the main objectives in studying the history of language.

The investigation of sources includes search, collection, systematization, printing, studying the written historical and linguistic sources. Such scientists as S.I. Kotkov and O.A. Blinova who defined theoretical and methodological bases of studying the linguistic sources, note that the language facts fixed in sources make its linguistic contents and material resources. O.A. Blinova, relying on the experiences of history, specifies the following stages of linguistic sources analysis:

I. External analysis of a source (establishment of the place and time of emergence, circumstances of its emergence, identification of the identity of the author, etc.)

II. Internal characteristics of a source ("interpretation", or description of its maintenance, establishment of its actual value).

III. Definition of the degree of reliability of the collected material.

IV. Identification of a level of informational content, opportunities and borders of a source [2, page 84-85].

Such way of a research of sources is widely used in scientific works.

\section{Literature review}

The Bashkir literary language has rich history, however the questions of its formation and development give rise to big disputes. There are several points of view on this problem. Some researchers consider that Bashkir before the October revolution had no writing. According to others, Bashkir is based on old script: the function of the literary language for Bashkirs in the XIII-XIX centuries was carried out by Turkic of the Uralo-Volga region on the basis of Arab script. I.G. Galyautdinov, E.F. Ishberdin, R.Kh. Khalikova adhere to this point of view. They divide development of the Bashkir literary language into two stages:

1) pre-national (from the $X X$ century till the end of the XX century);

2) national (from the beginning of the $X X$ century up to the present time) [3, page 8].

In comparison with other Turkic languages Bashkir was one of the poorly studied languages before revolution. Since the XVIII century there appear I.G. Georgi, P.S. Pallas, M. Bekchurin, P. Uchadamtsev's works containing the first data on Bashkir, on its grammatical system.

Folklore materials were not only collected but also translated into Russian by such authors as T. Belyaev, P.M. Kudryashov, V.I. Dahl, I.P. Pokrovsky. M. Ivanov was one of the first to realize the need of the public literary language and fix the samples of informal conversation, folklore. The invaluable role in formation and development of the Bashkir literary language was played by M. Ivanov, M.A. Kazembek, S. Kuklyashev, M. Bekchurin who reflected various features of its development in their works.

The great contribution in the field of linguistics was made by the famous Bashkir educator, the scientist and the poet M. Umetbayev. The two-volume "Comparative dictionary of the Turkish-Tatar dialects" of L.Z. Budagov (1869, 1870) containing valuable data on Bashkir lexicon, phonetics and grammar deserves special attention.

In the 70-80-s of the XIX century there appeared the first Bashkir texts on the basis of the Russian script, the Bashkir alphabet, textbooks, dictionaries were formed on the basis of Cyrillics. A wide range of questions was discussed in R.G. Ignatyev, M.V. Lossiyevsky-Ufimsky, S.G. Rybakov, N.I. Ilminsky, M.G. Kuvatov, V.V. Katarinsky, A.G. Bessonov, N.F. Katanov, M.A. Kulayev's works. Though all listed works allow to investigate Bashkir not in common, but only in particular, at the end of the XIX century there was a tendency of systematic study of Bashkir that caused the development of the national literary language.

A lot of work on collecting, scientific research and putting the written sources into a chronological order was done in Bashkir linguistics. The works of famous turcologist, professor N.K. Dmitriyev are of great value. The scientist studied Bashkir history till the 20-s of the XX century and made the bibliography of written sources of that era. He also published the Bashkir fairy tales collected and translated to Russian by A.G. Bessonov at the end of the XX century. N.K. Dmitriyev showed high appreciation of A.G. Bessonov's linguistic and folkloristic activity, noted that "he had very deep actual knowledge" on Bashkir, that the language facts collected by him now "gain character of a peculiar 
document on history of the separate language and folklore phenomena" [4, page 7].

T.M. Garipov's article devoted to studying of Bashkir during the pre-revolutionary period is of great importance. The article contains a short review of works of the Bashkir educators, Russian and foreign turcologists on Bashkir and gives their list in alphabetical order. The significant contribution to a research of written sources was made by famous Bashkir linguists K.Z. Akhmerov and J.G. Kiyekbayev.

This problem is also reflected to some extent in A.A. Yuldashev, A.N. Kononov, N.A. Baskakov, A.I. Kharisov's works. Without belittling the value of these scientists' works, it is necessary to emphasize that they contain mainly general characteristics of the written sources. The process of formation of the Bashkir literary written language was investigated by V.Sh. Psyanchin on the basis of the linguistic analysis of written sources. As it has been mentioned above, the most important steps in this direction have been taken by E.F. Ishberdin, I.G. Galyautdinov, R.Kh. Khalikova. Their collective work [3] holds a specific place in the study of written sources.

Though a lot of things have been done in this direction, there are still unsolved problems. The present work is devoted to the linguistic description, analysis and systematization of the poorly studied written sources of this period written on the basis of Russian and Latin scripts.

\section{Discussions and results}

Creation of the first alphabets on the basis of Cyrillics for the non-Russian people is connected with missionary policy of Christianization. In the 60-s of the XX century the expert on Turkic languages, the famous missionary N.I. Ilminsky offers the special system based on education of foreigners in their native language, i.e. "with the use of their live national spoken language and with application to language for the letter and printing of the Russian alphabet" [5]. N.I. Ilminsky's pedagogical system was based on two principles: 1) the translation of Christian spiritual compositions into a foreign language in "colloquial style"; 2) printing them on the basis of Russian letters. He believed that the alphabet for nonRussian nationalities will alienate them from Islam and will pull together with Christianity and Russian.

At the end of the XIX - the beginning of the XX centuries, the edition of orthodox and religious literature was carried out in Tatar, Kazakh, Chuvash, Karaim, Bashkir and many other Turkic languages of Russia. At that period, four religious books were translated into Bashkir. The books were published on the basis of the Russian script, for the presentation of specific Bashkir sounds additional diacritical signs were used. The books described the most widespread characteristic features of eastern and southern dialects on which the standards of the modern Bashkir literary language were developed. S.E. Malov, V.A. Gordlevsky, O.N. Betling, E.K. Pekarsky, P.A. Sleptsov - all these researchers-linguists consider missionary literature among important written sources in studying the language history. Kazakh scientist B.Kh. Abilkhasimov notes that "today missionary editions are valuable as the linguistic source reflecting not only lexical richness of language, but also the various phenomena of informal conversation" [1, page 43-44].

N.I. Ilminsky paid attention to a huge difference between colloquial and bookish languages, to discrepancy of the Arab alphabet to the Bashkir phonetics and its inability to express its sound features. $\mathrm{He}$ considered national language as the original document for linguistic researches, and bookish language (i.e. Turkic in the Uralo-Volga region), according to him, represented more or less artificial casual mixture of different languages and dialects.

The scientist was the first to publish the Bashkir text using the Russian script in his work "Introduction to the course of the Turkish Tatar language ...". He "decided to publish it due to scarcity of printed texts in the Bashkir dialect" (language) since "except for M. Ivanov's two or three sketchy notes, the first data were reported by $\mathrm{M}$. Bikchurin ...". According to N.I. Ilminsky, both texts "contain insignificant data about the properties and laws of the Bashkir dialect". "It is possible to investigate the Bashkir adverb in detail and precisely only in Bashkiria, - he notes. - It is necessary to write down the stories which Bashkir is rich in" [6, page 58]. N.I. Ilminsky guesses that Bashkir is divided into dialects. He pays attention to such specific phonetic and grammatical features of Bashkir as the use of a "deep and respiratory" sound instead of $\boldsymbol{c}$, replacement of $\boldsymbol{\partial}$ by the somnd $\boldsymbol{\mu}$ in the inflections and vice versa.

For writing the Bashkir words the author used 30 letters, designating specific Bashkir sounds by special

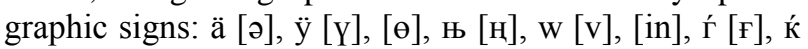
$[\mathrm{K}], \mathrm{h}[\mathrm{h}]$. The main lexicon of the text is primarily made by Bashkir words.

The text is written in the southern Bashkirs' spoken language. Despite some drawbacks of the text, this source played a huge role in the formation of Bashkir alphabet on the basis of the Russian script. N.I. Ilminsky's works subsequently promoted formation of Russian-based Bashkir writing.

The first $\mathrm{ABC}$ book in the Bashkir language was published without the author's indication in Orenburg in 1892, it was republished in 1898 and 1908 [7]. The volume of the book consisted of 58 pages. J.G. Kiyekbaev, whose opinion is supported by other scholars, suggests that the author of this $\mathrm{ABC}$ book could be Vladimir Katarinsky. The comparison of ABC with other works of V. Katarinsky confirms this version [1, page 54].

The introductory part of the book contains the brief information about the specific features of Bashkir sounds and their graphic signs. The author shows the difference between the Bashkir and Tatar languages, namely the pronunciation of the Tatar [ж] and Bashkir [й], [с] и [к]. The ABC book consists of two sections: Bashkir and Russian. For their transfer, the author used 39 (including for the record of native Bashkir - 29) letters. The sounds in this work are called the voice (mayblu)), and letters 
are the signs of the voices (таушнен билгеѓe). Vowel sounds are called as easy signs (анѓат тауышларнен билдӓлӓре), and consonant - "signs of difficult sounds" (кыйын тауышларнен билдӓлӓре). "The letters are followed by numbers and various texts for reading. This section of the ABC book is completed by instructive short stories - "Ике баланын тӧзӓлеӱе" ("The correction of two children"), "Абтраган карт" ("The exhausted man”), “Ходай йятимлӓрзе ташламай” ("God does not leave orphans"), “Тӱземлек" ("Tolerance"), "Йаман юлдашлар" ("Bad companions"), "Ике ибтӓш" (“Тwo friends"), and also proverbs, sayings and riddles. Despite the fact that the stories are translated from Russian into Bashkir, the language retains features of ik- sakmarskiy patois of the southern dialect. The second section of the ABC book "Russian alphabet" - was written to teach the Russian language to Bashkir children. First, the Russian alphabet is given, and then, on the basis of the principle "from easy to difficult" - texts reflecting the peculiarities of the Russian language. Most of them are texts familiar from the Bashkir section. There are instructions, original poems, fables" [8, page 103-104].

"ABC book for the Bashkirs" by V.V. Katarinsky was not only an educational publication, according to which students first learned to read and write in their native Bashkir and Russian languages, but also had great importance in the spiritual and moral education of the younger generation. The author has created this unique textbook, knowing well the people's national traditions and everyday life of the Bashkirs, and children in accordance with their mentality, in an accessible form is given a certain amount of knowledge about God, religion, ethics and morality. The material of the ABC book is focused on the formation of an obedient, Godfearing disciple who unquestionably worships and serves God, at the same time, on the basis of a purposeful educational policy, the requirements and the level of the era, is called to educate a citizen who meets state needs, is useful to the Fatherland, as well as a person who is confident in his spiritual and moral self-determination. The educational material of the second part of the book is not limited only to the named topic, it contains sayings, proverbs, riddles, poems, individual texts related to God, work, wealth and poverty, good and evil, and just life.

V.V. Katarinsky is also a pioneer of Bashkir lexicography. The first "Brief Russian-Bashkir dictionary" was published in Orenburg in 1893 without the instruction of the originator [9]. In 1899 there appeared the "Bashkir-Russian dictionary " by V. Katarinsky [10]. The introductory parts of these dictionaries are almost identical. This fact gives reason to assume that the originator and the first compiler is V.V. Katarinsky, who was at that time an inspector of the Russian-foreign schools of the Orenburg educational district and was engaged in the creation of dictionaries and letters for Bashkirs and Kazakhs. He often turned for help to M. G. Kuvatov and M. Umetbaev. These dictionaries were the educational textbooks. The volume of the Russian-Bashkir dictionary is 92 pages, it gives Bashkir equivalents of 2,173 Russian words, which are considered in 43 thematic groups. The Bashkir-Russian dictionary, the volume of which is 237 pages, contains 2,619 Bashkir capital words given in alphabetical order. In work the attention is paid also to the principles of the compilation of data dictionaries, the lexical level of words, included in their composition, is discussed in detail. The spoken language of the Bashkirs in Orenburg was put in the basis of the dictionaries, now it is the part of the ik-sakmarskiy patois of the southern dialect. In 1907 in Kazan "ABC book for the Bashkirs" was published by A. G. Bessonov (volume - 46 p., edition limited to 2000 copies) [11]. His ABC book is considered to be more perfect in comparison with V. V. Katarinsky's alphabet. In A. G. Bessonov's ABC book 42 letters are used for transmission of sounds, writing of letters and their elements, division of words into syllables is shown, words, phrases, sentences are given. This work is a great value in our time: the author first gave valuable information from the field of phonetics of the Bashkir language, the main thing is the presentation of the Bashkir alphabet based on the Cyrillic script. Unlike Vladimir Katarinsky, he introduced primary ABC teaching period, calligraphic patterns. There are also texts for reading in two languages - in Russian and Bashkir, logical exercises with the use of images and illustrations. A.G. Bessonov practically implemented sound analytic-synthetic method of teaching alphabet founded by K. D. Ushinsky. Texts for reading are informative by nature and present the best examples of folklore. Also interesting is the fact that the texts are given in three versions, taking into account the dialect features of the Bashkir language.

A. G. Bessonov used his version of the alphabet for recording the Bashkir folk tales. A. G. Bessonov is also the founder of the Bashkir dialect science: for several years he studied the spoken language of the Bashkirs, its dialects and their features. His research in the field of dialectology is described in such works as "The first book after the book for reading of North-Eastern Bashkirs" (Kazan, 1906), "The first book after the book for reading of South-Eastern Bashkirs" (Kazan, 1907) [12]. Each of these books was published with a circulation of 1,200 copies and the volume of 56 pages. The first part of the books are Bashkir texts which literally coincide with the language materials given in the ABC book of V. Katarinsky, and differ only in some phonetic, dialect features. The second part is devoted to practical lessons and reminds Russian-Bashkir phrase book.

In the National archives of the Republic of Tatarstan, the handwritten " $\mathrm{ABC}$ for the Bashkir language" by N.F. Katanov [13] is stored which proposes the alphabet of 33 letters with the use of superscript signs to indicate specific sounds of the Bashkir language. Special attention is paid to orthoepic norms of specific Bashkir sounds, to the difference of Bashkir [o], [x], [s], [e] from similar Russian sounds. The translation of the fables "The dragonfly and the ant" by I. A. Krylov in the Bashkir language is given for reading.

M. A. Kulaev is the author of two Bashkir ABC books. His first book entitled "Fundamentals of pronunciation and $\mathrm{ABC}$ for the Bashkirs" was published 
in Kazan in 1912 (21 pages), the methods of formation of Bashkir sounds are described in detail and schemes are given in it [14]. The author offers an alphabet of 34 letters, compiled on the basis of Russian and Greek scripts. In 1919, M. A. Kulayev secondarily compiled and released a more advanced version of the Bashkir alphabet. "Alepei" consisted of three parts (35 p.). In the second alphabet M. A. Kulayev refused the dialect sound [j] - [дж].

"The author has repeatedly appealed to the government on the expediency of the adoption of the Bashkir national writing on the basis of Russian script. Unfortunately, at that time it was decided in favor of the Arabic alphabet, since the educated part of the Bashkir population consisted mainly of those who could read and write the Arabic alphabet. The sound-letter system of M.A. Kulayev was correct, because it corresponded to the basic provisions of sound- analytical and synthetic method. Indeed, in 1939 the Bashkir writing system started to use the Russian script, which was introduced during 1940-1942" [15, page 43].

In the $\mathrm{ABC}$ books, books for reading and dictionaries of V.V. Katarinsky, A.G. Bessonov, N. F. Katanov, M. A. Kulayev the specific Bashkir sounds marked with special signs. There are any similarities in the alphabets of Russian scientists who used Russian letters with special diacritical marks for the transfer of the Bashkir sounds. M.A. Kulayev's alphabet was made up of Russian and Greek letters.

Alphabets of M. A. Kulayev and N.F. Katanov most fully reflect the sound composition of the Bashkir language. In all the named alphabets there are no letters

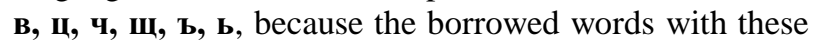
letters were pronounced according to the phonetic norms of the Bashkir language.

In all sources, spelling of words is based on the phonetic principle. Words with consonants [v] acquired in the modern spelling through a letter, issued in the following way: yaкbım/lyaxblm (modern spelling вакыт 'время'), үӓгӓдӓ// үӓвӓзӓ (вәzәз̧ә 'обещчание'). The letters я, ю, е are transmitted by the combinations йа, йу, йе: йаз (яз 'весна'), йул (юл 'nуть, дорога'), йел (ел 'ветер). Unfortunately, when compiling the modern Bashkir alphabet based on the Cyrillic script (1940), these points were not taken into account. The absence of graphic symbols with some specific sounds should be considered as fault of modern writing.

The authors of the sources knew the peculiarities of the studied language well. Some suspension of the law of synharmonism is observed only in the works of V. Katarinsky.

The content of the accumulated material shows that the dictionary compilers were familiar with the life, traditions, customs, occupations, history of the Bashkir people. A large place is occupied by samples of folk art. The lexical composition of the sources is almost identical to the modern Bashkir literary language, its main layer consists of native Bashkir words, borrowed words are very few. The dictionary contains only the words which were borrowed a long time ago and have become an integral part of the studied language.
The written monuments clearly reflect the phonetic, lexical and grammatical peculiarities of Bashkir speech and dialects. If in the works of V. V. Katarinsky and M. A. Kulayev the traits of the southern dialect prevail and in the works of A. G. Bessonov, N. F. Katanov the Eastern dialect dominates. Grammatical forms are identical to the modern Bashkir language. There are no differences in the construction of syntactic structures. Of course, the lack of common spelling rules caused different spelling of the same words. However, there is a desire to solve spelling issues. The questions of orthoepy were raised by M. A. Kulayev and A. G. Bessonov.

Thus, the studied ABC books, textbooks, dictionaries had great practical significance for their time. They contributed to the development of language norms based on the national Bashkir spoken language. The authors of the sources correctly outlined further ways of development of the Bashkir literary language and its writing.

\section{Conclusions}

In the course of the work, the following conclusions were made: the end of XIX and the beginning of XX centuries is the most important stage both in the history of language and in the history of the nation itself. Until the end of the XIX century, the Turkic language of UralVolga region based on the Arabic script was used as the Bashkir written literary language. However, it could not fully meet the needs of the Bashkir people. The abundance of Arabic, Persian words in the literary language, the presence of ancient elements removed it from the living spoken language. In addition, the Arabic alphabet did not fully reflect the original Bashkir sounds. During the investigating period the possibility of formation of the Bashkir literary language was revealed based on spoken language, brave steps has been made towards the creation of writing, reflecting phonetic peculiarities of the Bashkir language. It was at this time that the original versions of the modern Bashkir alphabet on the basis of the Russian script were proposed.

Advanced teachers and figures of national education as V.V. Katarinsky, A.G. Bessonov, N.F. Katanov and others have done much to educate the local population, to develop their identity, to create writing and literary language, as well as to improve public education. The representatives of Bashkir intelligentsia as M. A. Kulaev, M. G. Kuvatov and others, joining the advanced Russian culture, called their people to knowledge and education.

In all considered sources specific Bashkir sounds are marked with special signs. If N.I. Ilminskiy, V.V. Katarinski, A.G. Bessonov, N. F. Katanov for transfering used similar pronunciation of Russian sounds, with special diacritical marks, M. A. Kulaev marked them with some modified Russian-Greek letters. The alphabets of M.A. Kulaeva and N. F. Katanov fully reflect the sound system of the Bashkir language. The Bashkirs adapted borrowed Russian words to phonetic norms of their language, so in all alphabets there are no

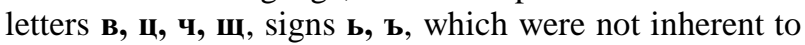
Bashkir speech. 
The works of V.V. Katarinsky, A.G. Bessonov, M.A. Kulayev were written on the basis of spoken language. The vocabulary of the sources is made up of native Bashkir words, very few borrowed words are used, with the exception of Arabic, Persian words, which have already grown into the Bashkir language. And Russian words are given in an adapted form. Only in the works of V. Prole borrowed words occupy a significant place.

All these works are valuable for Bashkir dialectology, as they reflect the phonetic, lexical and grammatical features inherent to different dialects. A.G. Bessonov was one of the first to divide the Bashkir language into 3 dialects, the differences of which are considered in his works. M.A. Kulayev has created textbooks on his southern dialect. If in the first works of V.V. Katarinsky the features of the southern dialect are mainly used, then in the last the features of the Eastern dialect prevail. N. F. Katanov studied dialects, comparing them with relative languages, he objectively managed to display the phonetic, morphological features of the Bashkir language. The grammatical forms fully correspond to the norms of modern Bashkir language. Now one can see infrequent verb forms -мак/-мәк. The structure of the sentences is no different from the current syntax constructions. However, due to the lack of common spelling rules at the time, there is no consistency in the spelling of some words.

In general, all the written sources help us to imagine the state of spoken Bashkir language in the late XIX and early XX centuries. They played an invaluable role in the history of the development of Bashkir national literature and national culture.

All experiments initiated and conducted by Russian scientists and representatives of the Bashkir intelligentsia in the creation of Bashkir writing on the basis of Russian script were the first significant step in the democratization of the Bashkir literary language. Despite the fact that before the October revolution there were serious aspirations in this area, they did not develop for a number of reasons: first, because they were offered by missionaries, the people were wary of it; secondly, the aristocracy of the tsar in every possible way hindered this work and continued to conduct national-colonial policy, as it was afraid of mastering the literacy of nonRussian nationalities, which would contribute to the emergence of national intellectuals with developed selfconsciousness, advanced views. Today, these sources, written on a phonetic basis in a live spoken language and reflecting all the linguistic features of the period under study, are significant for the history of the literary language and, in common, in General linguistics.

\section{Acknowledgements}

Special merits in formation of our scientific outlook belong to the Doctor of Science (Philology), Professor, Honored Scientist of the Russian Federation and the Republic of Bashkortostan, academician of Academy of Sciences of the Republic of Bashkortostan Z.G. Uraksin and the Doctor of Science (Philology), Professor, Corresponding member of Academy of Sciences of the
Republic of Bashkortostan I.G. Galyautdinov. We are grateful to them for their help and support throughout our scientific activities.

We express our deep gratitude to the responsive researchers from the Institute of history, language and literature of the Ufa scientific center of the Russian Academy of Sciences, colleagues from the Sibai Institute (branch) of the Bashkir state University, because they helped us to learn more about the history of the Bashkir literary language in the process of collective discussion of this problem at seminars, academic councils and in free conversations.

\section{References}

1. R.M. Latypova, Written sources of the late XIX early $X X$ centuries and their influence on the formation of the Bashkir literary language on the basis of Russian and Latin scripts: Monograph. (Sibai, 2013)

2. O.I. Blinova, Languages and toponymy of Altai, 8389 (1981)

3. E.F. Ishberdin, I.G. Galyautdinov, R.Kh. Khalikova, The history of the Bashkir literary language (Kitap, Ufa, 1993)

4. Bashkir folk tales. Record and translation by A.G. Bessonov. Foreword, comments and edition by Prof. N.K. Dmitriev (Ufa, 1941)

5. N.I. Ilminsky, On the system of enlightenment of foreigners and about the Kazan baptized Tatar school (Kazan, 1913)

6. N.I. Ilminsky, Introduction to the course of the Turkish Tatar language, with the applications of $N$. Ilminsky, the teacher of the Turkish-Tatar language of Kazan University (Kazan, 1862)

7. ABC book for the Bashkirs (Orenburg, 1892, 2nd ed., 1898)

8. I.G. Galyautdinov, Two centuries of Bashkir literary language (Gilem,Ufa, 2000)

9. A short Russian-Bashkir dictionary (Orenburg, 1893)

10. V.V. Katarinsky, Bashkir-Russian Dictionary (Orenburg, 1899)

11. A.G. Bessonov, ABC book for the Bashkirs (Kazan, 1907)

12. The first book for reading after $A B C$ and practical initial lessons of the Russian language for southeastern Bashkirs (Kazan, 1907)

13. N.F. Katanov, $A B C$ for the Bashkir language. Manuscript (NA RT. F. 969, Op 1, D. 26, L.1-3 vol.)

14. M.A. Kulayev, Fundamentals of pronunciation and $A B C$ for the Bashkirs (Kazan, 1912)

15. R.N. Karimova, R.M. Latypova, Ural-Altai studies 1 (20), 41-52 (2016) 